\title{
Quality of Eucalyptus Wood Grown in Rio de Janeiro State for Bioenergy
}

\author{
Ananias Francisco Dias Júnior ${ }^{1}$, Djailson Silva da Costa Júnior ${ }^{2}$, \\ Azarias Machado de Andrade ${ }^{3}$, Elisabeth de Oliveira ${ }^{4}$, Artur Queiroz Lana ${ }^{1}$, \\ José Otávio Brito ${ }^{5}$
}

\begin{abstract}
${ }^{1}$ Programa de Pós-graduação em Recursos Florestais, Escola Superior de Agricultura "Luiz de Queiroz" - ESALQ, Universidade de São Paulo - USP, Piracicaba/SP, Brasil

${ }^{2}$ Departamento de Ciências Vegetais, Universidade Federal Rural do Semi-Árido - UFERSA, Mossoró/RN, Brasil ${ }^{3}$ Departamento de Produtos Florestais, Universidade Federal Rural do Rio de Janeiro - UFRRJ, Seropédica/RJ, Brasil ${ }^{4}$ Unidade Acadêmica de Engenharia Florestal, Universidade Federal de Campina Grande - UFCG, Patos/PB, Brasil ${ }^{5}$ Departamento de Ciências Florestais, Escola Superior de Agricultura "Luiz de Queiroz" - ESALQ,
\end{abstract} Universidade de São Paulo - USP, Piracicaba/SP, Brasil

\begin{abstract}
This study aimed to evaluate the Eucalyptus grandis and Eucalyptus saligna, from production areas of Rio de Janeiro State, intended for energy use. The selection consisted of six trees per specie, at six years old. The wood samples had its basic density determined, then, was subjected to the pyrolysis process with $500{ }^{\circ} \mathrm{C}$ of final temperature. Charcoal, pyroligneous liquid and non-condensable gases yields were determined. In addition, the charcoal had its immediate analysis performed to determine the levels of volatiles matter, fixed carbon and ash content. Data were analyzed using descriptive statistics, Pearson correlation and principal component analysis. The correlation analysis and principal component analysis were effective to predict recommended species. Based on the results, the most recommended specie for energy purposes was the Eucalyptus grandis.
\end{abstract}

Keywords: forest biomass, wood for energy, charcoal.

\section{Qualidade da Madeira de Eucalyptus Cultivada no Estado do Rio de Janeiro para Bioenergia}

\section{RESUMO}

O presente estudo teve por objetivo analisar a madeira de Eucalyptus grandis e Eucalyptus saligna oriunda de áreas de produção do Estado do Rio de Janeiro com vistas ao uso energético. Selecionaram-se seis árvores por espécie, com seis anos de idade. Determinou-se a densidade básica da madeira e, em seguida, amostras de madeira foram submetidas ao processo de pirólise com temperatura final de $500{ }^{\circ} \mathrm{C}$. Foram determinados os rendimentos em carvão vegetal, em líquido pirolenhoso e em gases não condensáveis. Foi realizada a análise imediata do carvão, para a determinação dos teores de materiais voláteis, cinza e carbono fixo. Os dados obtidos foram analisados por meio da estatística descritiva, correlação de Pearson e análise de componentes principais. A análise de correlação e a análise de componentes principais foram eficientes na predição da espécie recomendada. Com base nos resultados, a espécie mais recomendada para fins energéticos foi o Eucalyptus grandis.

Palavras-chave: biomassa florestal, madeira para energia, carvão vegetal. 


\section{INTRODUCTION}

Brazil stands out in the global industry as the largest producer and, at the same time, the largest consumer of charcoal. It is also the only country that uses this source of energy for industrial purposes, e.g. in the manufacture of pig iron, steel and special alloys (AMS, 2009).

The species of the genre Eucalyptus are widely planted in Brazil due to the rapid growth and wood quality, for the production of cellulose, fiberboards, firewood, charcoal grill, construction, among other purposes. For energy purposes, there used species are: Eucalyptus grandis (Dias et al., 2015), Eucalyptus urophylla (Andrade, 2009), Eucalyptus camaldulensis, Eucalyptus cloeziana; (Pinheiro et al., 2005) Eucalyptus pellita (Oliveira et al., 2010); Eucalyptus saligna (Trugilho et al., 2001); hybrid Eucalyptus grandis $\times$ Eucalyptus urophylla (Trugilho et al., 2005), hybrid Eucalyptus grandis $\times$ Eucalyptus camaldulensis (Trugilho et al., 2005; Santos et al., 2011).

The eucalyptus cultivation in the state of Rio de Janeiro is insufficient to meet its needs. The area planted with eucalyptus reforestation is 18.4 thousand hectares, corresponding to $0.42 \%$ of the state's total area, and less than $0.1 \%$ of planted forests area in the country (Paula et al., 2012). Rio de Janeiro stands out on the national scene, being a large importer of wood and derivatives, mainly charcoal, for different purposes (Amorim et al., 2012). The choice of the conversion process and use of forest biomass, as well as the possible processing difficulties, vary according to the type of biomass available. Thus, it is of paramount importance to pre-assess the biomass to direct it to the best conversion technology and use, avoiding exploitation of an expensive biomass and that has low energy efficiency. The biomass characteristics are based on their physical (particle size, density, specific gravity and moisture content) and chemical properties, influencing the quality of charcoal and its calorific value, higher heating value (Vieira, 2012).

Several authors have reported the density as the main factor of choice of wood for energy purposes. According to Brito et al. (1982), the knowledge of correlations between the density of charcoal and the basic density of wood, it is a best practice from the aspect of industrial use of charcoal. In charcoal production, the wood is subjected to heating, where it undergoes thermal treatment in controlled presence of oxygen, releasing gas fractions and generating charcoal (Assis et al., 2008). Oliveira et al. (1982) state that part of the gaseous fraction is composed of condensable gases, generating pyroligneous liquor and tar. Gases as $\mathrm{CH}_{4}, \mathrm{CO}_{2}, \mathrm{CO}, \mathrm{H}_{2}$ and hydrocarbons are formed during the process, which some can be used as fuel or on the carbonization process, are basically, the remaining.

The control of the chemical composition of charcoal is important, once its effect reflects the use, e.g. the productivity of the blast furnace per unit volume. To determine the constituents of charcoal, among other tests, the immediate chemical analysis is conducted, which aims to quantify fixed carbon, volatiles matter and ash content.

The higher heating value is another property that can direct the use of charcoal for energy purposes, being among the main selection criteria (Paludzysyn, 2008). Nogueira \& Lora (2003), state that the calorific value is the amount of calories released by a material in its complete combustion in terms of content for energy, per unit mass or volume.

This study aimed to analyze the quality of wood and its charcoal for bioenergy, testing Eucalyptus grandis and Eucalyptus saligna grown in the city of Paty do Alferes, in the state of Rio de Janeiro, indicating their potential as source of bioenergy.

\section{MATERIAL AND METHODS}

The experiment were performed in December 2005 in an area belonging to the company Rigotex Textile, located in Paty Alferes, Rio de Janeiro State, Brazil. The samples were six trees of Eucalyptus grandis and six trees Eucalyptus saligna, all of them six years old, selected plants with good health. The Eucalyptus grandis had an average of $15.2 \mathrm{~cm}$ at diameter at breast height (DBH $-1.3 \mathrm{~m}$ ) and a height average total of $24.1 \mathrm{~m}$, and, for Eucalyptus saligna, the average value of DBH was $15.1 \mathrm{~cm}$ and the total height of $20.3 \mathrm{~m}$.

Each tree provided six wood discs, or samples, for the analyses, approximately $2.5 \mathrm{~cm}$ thick, removed at the base, at diameter at breast height (DBH - $1.3 \mathrm{~m}$ ), at $25 \%, 50 \%, 75 \%$ and $100 \%$ of commercial bole. After identified the samples went to the Wood Energy Laboratory, in the Department of Forest Products, of 
Forestry Institute, in the Federal Rural University of Rio de Janeiro, city of Seropédica, Rio de Janeiro State, Brazil. The wood chipper transformed the discs into wood chips, then, homogenized by species, and then subsamples were taken for further analysis.

\subsection{Tests performed}

The wood basic density was determined in accordance with the hydrostatic method according to NBR 11941 (ABNT, 2003) and Vital (1984), by water displacement method, where the saturated chips were immersed in water, the displaced volume of water is equal to the volume of wood. Then, they have their weight measure after complete dried out of water at $105 \pm 3{ }^{\circ} \mathrm{C}$, thus, having mass and volume were calculated the density.

The carbonization of the wood chips used an average of $100 \mathrm{~g}$ of pre-dried chips at electric hot air oven at $105 \pm 3^{\circ} \mathrm{C}$ to constant weight. The carbonization passed in a muffle furnace, for five hours, starting from ambient temperature until reaching a maximum temperature of $500^{\circ} \mathrm{C}$, being the increase of temperature of $1.67^{\circ} \mathrm{C}$ per minute. The condensable gases from the pyrolysis were cooled by two "Liebig" condensers, installed in line, and collected in a beaker. The non-condensable gases were burned at the output capacitor before being released into the air (Figure 1).

The charcoal gravimetric yield was determined by the ratio of the mass of produced charcoal and the mass of dried wood put into the furnace, expressed in percentage, as well as the amount of condensate liquid pyroligneous and, by difference, the non-condensable gases.
The charcoal apparent density was determined based on the procedures performed by Dias et al. (2015). The higher heating value of charcoal was determined with the aid of a calorimeter Ika C2000 model following procedures for NBR 8633 (ABNT, 1984). The chemical immediate analysis was performed based on the standard of NBR 8112 (ABNT, 1986). The yield of fixed carbon was calculated by multiplying the gravimetric yield by fixed carbon content.

\subsection{Data analysis}

The data were analyzed using descriptive statistics. However, whenever relevant, they were submitted to normality test (Shapiro Wilk) and homoscedasticity of variances (Levene). Verified these assumptions, we used the Student $t$ test for independent samples, at $95 \%$ of probability. In order to verify the relationship between variables was performed Pearson correlation analysis.

The principal component analysis (PCA) was performed aimed to recognizing the most important features for the studied species, following the procedures described by Mingoti (2005) and Manly (2008). It was considered standardized mean (mean 0 and variance 1 ) for each test of each treatment. For the analysis of main components used the data correlation matrix. The established linear combinations were interpreted by means of the normalized eigenvectors and the correlations between the original variables and the principal components. All data were analyzed with the aid of Minitab $16.1^{\circledR}$ software.

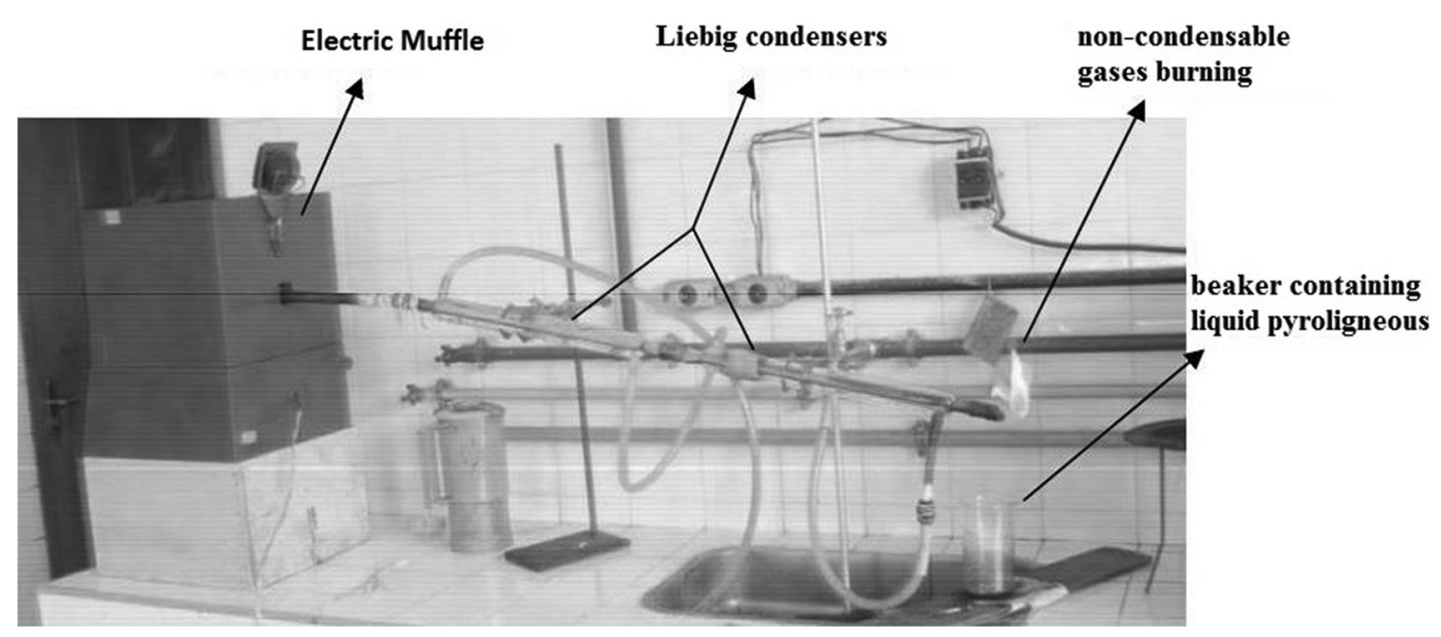

Figure 1. Condensation system coupled to the oven type mufla. 


\section{RESULTS AND DISCUSSION}

The Eucalyptus grandis and Eucalyptus saligna wood had basic density mean of $0.445 \pm 0.02 \mathrm{~g} \mathrm{~cm}^{-3}$ and $0.442 \pm 0.03 \mathrm{~g} \mathrm{~cm}^{-3}$, respectively, differing $0.67 \%$ one each other. There was no significant difference between the values by Student's t test. Dias et al. (2013), obtained for some species of Eucalyptus, twenty years old, cultivated in the city of Seropédica, state of Rio de Janeiro, found the basic density ranging from 0.490 to $0.808 \mathrm{~g} \mathrm{~cm}^{-3}$. Hence, would be inferred that age affects this property.

The charcoal apparent density was $0.34 \pm 0.04 \mathrm{~g} \mathrm{~cm}^{-3}$ for E. grandis and $0.32 \pm 0.03 \mathrm{~g} \mathrm{~cm}^{-3}$ for E. saligna, having no statistical difference between them. This property is mainly affected by raw material and process.

Table 1 shows the average values and deviations observed in the evaluated characteristics.

Among other factors involved in the carbonization process, it is expected for a given plant species, that the higher the maximum temperature of carbonization the lower gravimetric charcoal yield. Several authors have reported the existence of a significant relationship between the gravimetric yield and the carbonization maximum temperature (Brito, 1990; Andrade, 1993). This research showed that the E. saligna presented the highest yield of charcoal, despite being subject to the same conversion conditions and equality of evaluated basic densities of the woods. Under the conditions set for the carbonization of wood, it was observed that the average yield of pyroligneous liquid was significantly higher for Eucalyptus saligna, showing the influence of the species in this aspect.

The basic wood density affects the yields of pyroligneous liquid and non-condensable gases, as well as its chemical constitution and the conditions laid down for its conversion into charcoal. The mean values found in this study were similar to those observed by Reis et al. (2012) analyzed Eucalyptus urophylla adopting the maximum temperature of $450^{\circ} \mathrm{C}$, demonstrating the high influence of the conversion conditions on the pyrolysis yields.

In the case of higher heating value (HHV), the average figures were $7521 \pm 136 \mathrm{kcal} \mathrm{kg}^{-1}$ and $6982 \pm 148 \mathrm{kcal} \mathrm{kg}^{-1}$, for the charcoals of Eucalyptus grandis and Eucalyptus saligna, respectively, being Eucalyptus grandis HHV statistically superior. Rocha (2011) and Reis et al. (2012) studying eucalyptus charcoal, found lower values than in this work. It was due, possibly, by conditions of pyrolysis, the planting of site implantation, and chemical composition of wood, and, hence, the chemical composition of charcoal. Studies conducted by the Technology Foundation of Minas Gerais, published by Mendes et al. (1982) showed that the higher heating value of charcoal varies according to the carbonization temperature. Charcoal produced at a temperature of $500^{\circ} \mathrm{C}$ have higher calorific value than those produced at $300{ }^{\circ} \mathrm{C}$ and $700{ }^{\circ} \mathrm{C}$.

Observed that the average charcoal levels of volatiles matter, which differed statistically from one another, were $5.83 \%$ and $13.33 \%$ for Eucalyptus grandis and Eucalyptus saligna, respectively. Depending on their lower content of volatiles matter, charcoal of Eucalyptus grandis showed fixed carbon content statistically superior. The ash content levels and yields on fixed carbon showed no significant differences. The values obtained showed that the both analyzed species can be used for energy purposes, especially in the State of Rio de Janeiro, where there is a lack of this type of fuel. From chemical analysis of charcoal and, based on the fixed carbon content can be estimated the high heating value (HHC), being this kind of great importance in energy correlation analysis. The Table 2 shows the correlation matrix.

Table 1. Average values and standard error of the tests performed.

\begin{tabular}{llllllll}
\multicolumn{1}{c}{ Specie } & GY & PL & NG & VM & AC & FC & FCY \\
Eucalyptus grandis & $23.45^{\mathrm{b}}$ & $45.42^{\mathrm{a}}$ & $31.13^{\mathrm{ns}}$ & $5.83^{\mathrm{b}}$ & $2.50^{\mathrm{ns}}$ & $91.67^{\mathrm{a}}$ & $28.57^{\text {ns }}$ \\
Standard error & \pm 0.35 & \pm 0.80 & \pm 0.46 & \pm 0.83 & \pm 1.12 & \pm 1.67 & \pm 0.86 \\
Eucalyptus saligna & $25.71^{\mathrm{a}}$ & $42.28^{\mathrm{b}}$ & $32.02^{\mathrm{ns}}$ & $13.33^{\mathrm{a}}$ & $1.67^{\mathrm{ns}}$ & $85.00^{\mathrm{b}}$ & $27.21^{\mathrm{ns}}$ \\
Standard error & \pm 0.14 & \pm 0.76 & \pm 0.77 & \pm 1.67 & \pm 1.05 & \pm 1.83 & \pm 0.89 \\
\hline
\end{tabular}

Where: $\mathrm{GY}=$ charcoal gravimetric yield (\%); $\mathrm{PL}=$ yield of pyroligneous liquor (\%); NG = yield of non-condensable gases (\%); $\mathrm{VM}=$ charcoal volatile matter (\%); $\mathrm{AC}=$ charcoal ash content (\%); FC = fixed carbon content (\%); FCY = fixed carbon yield. Means followed by the same letter, in each column, do not differ statistically ( $t$ de student, $\mathrm{p}>0.05$ ). $n s=$ non-significant values. 
From Table 2 can be inferred the existence of positive and significant association between: volatiles matter and yield of charcoal; fixed carbon yield and fixed carbon content; charcoal higher heating value and fixed carbon content and between charcoal fixed carbon yield and higher heating value. Significant decreasing relationships were observed between the ash content of coal and apparent density; charcoal gravimetric yield and yield of pyroligneous liquid; non-condensable gases yield and yield of pyroligneous liquid; fixed carbon content and volatiles matter; higher heating value and volatile matter and between the yield of fixed carbon and volatiles content.

The study of the relationship is important to choose the best kind targeting a specific use. Santos et al. (2011) and Reis et al. (2012) found significant correlations between various Eucalyptus spp. characteristics and the fact that some chemical constituents provide increases in charcoal yield and fixed carbon yield. It is worth noting that this study shows the energy results for one of the first commercial plantations established in the State of Rio de Janeiro and the local information, which could serve as a basis, once they are still scarce.

The principal component analysis is able to describe the general variation of the analyzed characteristics, allowing measure the variation over a few variables, considering not negligible variations. Thus, a large number of original variables are reduced to a small number of transformed variables (Manly, 2008). Looking at Figure 2 (scree plot) it is possible note that about $70 \%$ of the total variation of the energy characteristics evaluated in this study is focused on all the components 1 and 2 .

Table 2. Pearson correlation matrix obtained from the variables studied.

\begin{tabular}{|c|c|c|c|c|c|c|c|c|c|}
\hline Variable & D & AD & PL & GY & NG & VM & $\mathrm{AC}$ & FC & HHV \\
\hline $\mathrm{D}$ & 1 & & & & & & & & \\
\hline $\mathrm{AD}$ & 0.24 & 1 & & & & & & & \\
\hline PL & 0.25 & -0.23 & 1 & & & & & & \\
\hline GY & -0.15 & 0.12 & $-0.82^{\star}$ & 1 & & & & & \\
\hline NG & -0.27 & 0.25 & $-0.87^{\star}$ & 0.44 & 1 & & & & \\
\hline VM & -0.12 & -0.06 & -0.41 & $0.67^{\star}$ & 0.07 & 1 & & & \\
\hline $\mathrm{AC}$ & 0.26 & $-0.60^{*}$ & 0.22 & -0.29 & -0.10 & -0.10 & 1 & & \\
\hline FC & -0.01 & 0.35 & 0.27 & -0.48 & -0.02 & $-0.88^{\star}$ & -0.38 & 1 & \\
\hline $\mathrm{HHV}$ & -0.01 & 0.35 & 0.27 & -0.48 & -0.02 & $-0.87^{\star}$ & -0.39 & $0.98^{\star}$ & 1 \\
\hline FCY & -0.18 & 0.44 & -0.34 & -0.11 & $0.62^{*}$ & $-0.64^{*}$ & -0.37 & $0.77^{*}$ & $0.77^{*}$ \\
\hline
\end{tabular}

Where: $\mathrm{D}=$ wood basic density $\left(\mathrm{g} \mathrm{cm}^{-3}\right) ; \mathrm{AD}=$ charcoal apparent density $\left(\mathrm{g} \mathrm{cm}^{-3}\right) ; \mathrm{PL}=$ yield of pyroligneous liquor (\%); GY = charcoal gravimetric yield (\%); $\mathrm{NG}=$ yield of non-condensable gases (\%); $\mathrm{VM}=$ charcoal volatile matter (\%); $\mathrm{AC}=$ charcoal ash content (\%);

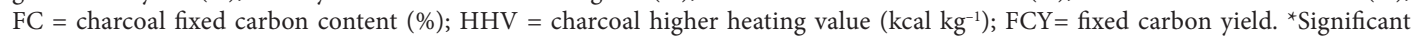
values at $95 \%$ probability.

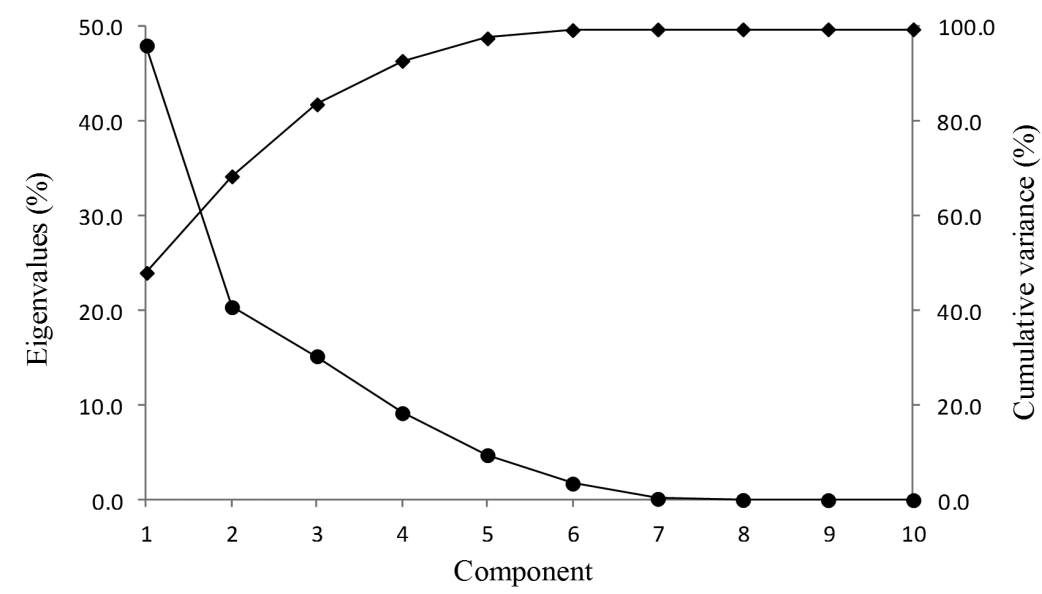

Figure 2. Variance explained cumulative and eigenvalues obtained by correlation matrix. 
The variances of the main components correspond to the eigenvalues, it follows that the sum of the variances of the principal components is equal to the sum of the variances of the original variables. So, analyzing in module Table 3, observed that the first principal component are contained the highest values for fixed carbon yield, fixed carbon content and higher heating value.

In the second main component, the observed higher values were to charcoal gravimetric yield and wood basic density. These energy characteristics highlighted by the values of eigenvectors, the Eucalyptus grandis obtained the highest higher heating value and fixed carbon content, and only for charcoal gravimetric yield Eucalyptus saligna was superior. These results indicate multivariate analysis as a powerful tool that helps in forest biomass analysis for energy purposes.

The Figure 3 (biplot) shows the ordering of eigenvectors obtained based on Table 3 .

It is possible to observe, analyzing the graph, the dispersion of individuals of each species. It is noticed that some individuals are more distant from the

Table 3. Eigenvectors of the first two principal components.

\begin{tabular}{lcc}
\hline \multicolumn{1}{c}{ Variable } & Component 1 & Component 2 \\
\hline D - wood basic density & -0.021 & 0.405 \\
\hline AD - charcoal apparent density & 0.228 & 0.351 \\
\hline LP - yield of pyroligneous liquor & -0.332 & -0.343 \\
\hline GY - charcoal gravimetric yield & 0.163 & 0.503 \\
\hline NG - yield of non-condensable gases & 0.345 & 0.283 \\
VM - charcoal volatile matter & -0.341 & 0.249 \\
AC - charcoal ash content & -0.275 & 0.071 \\
FC - charcoal fixed carbon content & 0.392 & -0.309 \\
\hline HHV - charcoal higher heating value & 0.392 & -0.309 \\
FCY - charcoal fixed carbon yield & 0.435 & -0.041 \\
Explained variance (\%) & 48.07 & 20.49 \\
Cumulative variance explained (\%) & 48.07 & 68.56 \\
Eigenvalues & 4.80 & 2.04 \\
\hline
\end{tabular}

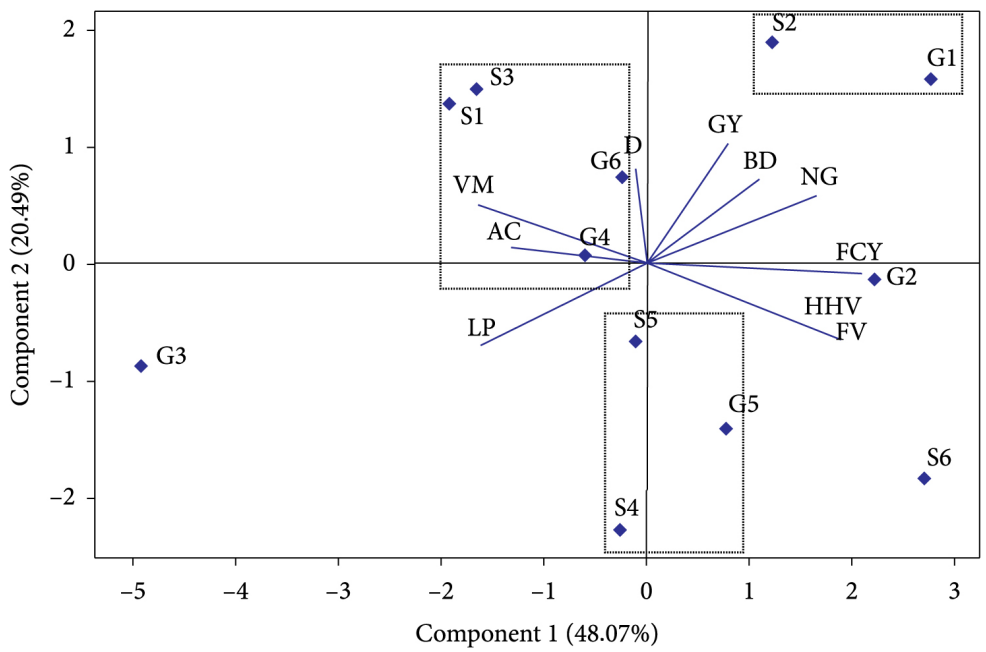

Figure 3. Diagram of ordination of two species considering the scores and eigenvectors of the principal components I and II. Where: G1, G2, G3, G4, G4, G5, G6; S1, S2, S3, S4, S5, S6 = corresponds to six individuals of Eucalyptus grandis and Eucalyptus saligna, respectively. D = wood basic density $\left(\mathrm{g} \mathrm{cm}^{-3}\right)$; GY = charcoal gravimetric yield (\%); $\mathrm{LP}=$ yield of pyroligneous liquid (\%); $\mathrm{NG}=$ non-condensable gases yield (\%); $\mathrm{AD}=$ charcoal apparent density $\left(\mathrm{g} \mathrm{cm}^{-3}\right) ; \mathrm{HHV}=$ charcoal higher heating value $\left(\mathrm{kcal} \mathrm{kg}^{-1}\right) ; \mathrm{VM}=$ charcoal volatile matter $(\%) ; \mathrm{AC}=$ charcoal ash content (\%); FC = charcoal fixed carbon content (\%); FCY = charcoal fixed carbon yield. 
others (G2, G3 and S6), but this fact can be attributed to randomization held for collection, where the site, climate and the hydro conditions are variables that must be considered. Taking into account that the closer the lines the greater is the positive correlation, and the opposite will be the largest negative correlation. The same ratios presented in Table 3 were detected in Figure 3. The principal component analysis is a powerful tool in the evaluation of individuals for selection purposes, it addresses broadly all the desired characteristics for a particular purpose.

\section{CONCLUSIONS}

The two evaluated eucalyptus species showed similar mean values for basic wood density, yield of non-condensable gases, charcoal apparent density, ash content and yield of fixed carbon.

The Eucalyptus grandis showed the highest average values for the yield of pyroligneous liquid, higher heating value and fixed carbon content, and can be considerate the most suitable for energy purposes.

The Eucalyptus saligna showed higher mean values for the gravimetric yield of charcoal and volatile matter.

The correlation analysis and principal component analysis helped predicting the species for energy use.

\section{ACKNOWLEDGEMENTS}

The authors acknowledge the Brazilian government agency of Coordination for the Improvement of Higher Education Personnel (CAPES) and the Institute of Forestry Research and Studies (IPEF) for the scholarship grants awarded.

\section{STATUS DA SUBMISSÃO}

Received: 2 apr., 2015

Accepted: 28 nov., 2015

\section{CORRESPONDENCE TO}

\section{Ananias Francisco Dias Júnior}

Programa de Pós-graduação em Recursos Florestais, Escola Superior de Agricultura "Luiz de Queiroz" - ESALQ, Universidade de São Paulo - USP, Av. Pádua Dias, 11, São Dimas,
CEP 13416-350, Piracicaba, SP, Brasil

e-mail: ananiasjr@usp.br

\section{REFERENCES}

Amorim HB, Francelino MR, Salamene S, Pedreira LOL, Assumpção LI Fo, Capitano RC et al. Estimativa da área ocupada por reflorestamento no Estado do Rio de Janeiro. Revista Cerne 2012; 18(1): 27-32. http://dx.doi. org/10.1590/S0104-77602012000100004.

Andrade AM. Efeitos da fertilização mineral e da calagem na produção e na qualidade da madeira e do carvão de eucalipto [thesis]. Viçosa: Universidade Federal de Viçosa; 1993.

Andrade CR. Espectroscopia no infravermelho próximo para predizer propriedades da madeira e do carvão vegetal de plantio clonal de Eucalyptus sp [dissertation]. Lavras: Universidade Federal de Lavras; 2009.

Assis CO, Trugilho PF, Mendes LM, Silva JRM, Lima JT. Sistema alternativo para carbonização de madeira. Scientia Forestalis 2008; 36(78): 133-140.

Associação Brasileira de Normas Técnicas - ABNT. NBR 8633: carvão vegetal: determinação do poder calorífico. Rio de Janeiro; 1984.

Associação Brasileira de Normas Técnicas - ABNT. NBR8112: Carvão vegetal: análise imediata. Rio de Janeiro; 1986.

Associação Brasileira de Normas Técnicas - ABNT. NBR 11941: madeiras: determinação da densidade básica. Rio de Janeiro; 2003.

Associação Mineira de Silvicultura - AMS. Números do setor [online]. Belo Horizonte; 2009 [cited 2013 July 24]. Available from: http://www.ciflorestas.com.br/ dosumentos. php? $\mathrm{t}=\mathrm{A}$

Brito JO, Barrichelo LEG, Muramoto MC, Couto HTZ. Estimativa da densidade a granel do carvão vegetal a partir de sua densidade aparente. Piracicaba: Instituto de Pesquisas e Estudos Florestais; 1982. n. 150.

Brito JO. Princípios de produção e utilização de carvão vegetal de madeira. IPEF 1990; 9(1): 1-14.

Dias AF Jr, Andrade AM, Soares VW, Costa DS Jr, Ferreira DAA, Leles PSS. Potencial energético de sete materiais genéticos de Eucalyptus cultivados no Estado do Rio de Janeiro. Scientia Forestalis 2015; 4(108): 833-843.

Dias AF Jr, Santos PV, Pace JHC, Carvalho AM, Latorraca JVF. Caracterização da madeira de quatro espécies florestais para uso em movelaria. Revista Ciência da Madeira 2013; 4(1): 93-107. http://dx.doi.org/10.12953/2177-6830. v04n01a08.

Manly BJF. Métodos estatísticos multivariados: uma introdução. 3rd ed. Porto Alegre: The Bookman; 2008. 
Mendes MG, Gomes PA, Oliveira JB. Propriedades e controle de qualidade do carvão vegetal. Belo Horizonte: Fundação Centro Tecnológica de Minas Gerais; 1982.

Mingoti SA. Análise de dados através de métodos de estatística multivariada: uma abordagem aplicada. Belo Horizonte: UFMG; 2005.

Nogueira LAH, Lora EESS. Dendroenergia: fundamentos e aplicações. 2nd ed. Rio de Janeiro: Interciencia; 2003.

Oliveira AC, Carneiro ACO, Vital BT, Almeida W, Corradi BL, Cardoso MT. Parâmetros de qualidade da madeira e do carvão vegetal de Eucalyptus pellita F. Muell. Scientia Forestalis 2010; 38(87): 431-439.

Oliveira JB, Gomes PA, Almeida MR. Estudos preliminares de normalização de testes de controle de qualidade de carvão vegetal: carvão vegetal: destilação, propriedades e controle de qualidade. Belo Horizonte: Fundação Centro Tecnológico de Minas Gerais; CETEC; 1982.

Paludzysyn E Fo. Melhoramento do eucalipto para a produção de energia. Revista Opiniões 2008; 1(1): 1-3.

Paula RP, Pereira MG, Santiago RR, Amorim HB. Propriedades edáficas e desenvolvimento de eucalipto em topossequência na Flona Mário Xavier-RJ. Revista Floresta e Ambiente 2012; 19(3): 344-351. http://dx.doi. org/10.4322/floram.2012.040.

Pinheiro PCC, Figueiredo FJ, Seye O. Influência da temperatura e da taxa de aquecimento da carbonização nas propriedades do carvão vegetal de Eucalyptus. Biomassa e Energia 2005; 2(2): 159-168.

Reis AA, Melo ICNA, Protásio TP, Trugilho PF, Carneiro ACO. Efeito de local e espaçamento na qualidade do carvão vegetal de um clone de Eucalyptus urophylla S.T.Blake. Floresta e Ambiente 2012; 19(4): 497-505. http://dx.doi. org/10.4322/floram.2012.055.

Rocha MFV. Influência do espaçamento e da idade na produtividade da madeira de Eucalyptus grandis $\times$ Eucalyptus camaldulensis para energia [dissertation]. Viçosa: Universidade Federal de Viçosa; 2011.

Santos RC, Carneiro ACO, Castro AFM, Castro RVO, Bianche JJ, Cardoso MT. Correlações entre os parâmetros de qualidade da madeira e do carvão vegetal de clones de eucalipto. Scientia Forestalis 2011; 39(90): 221-230.

Trugilho PF, Lima JT, Mori FA, Lino AL. Avaliação de clones de Eucalyptus para produção de carvão vegetal. Revista Cerne 2001; 7(2): 104-114.

Trugilho PF, Silva JRM, Mori FA, Lima JT, Mendes LM, Mendes LFB. Rendimentos e características do carvão vegetal em função da posição radial de amostragem em clones de Eucalyptus. Revista Cerne 2005; 11(2): 178-186.

Vieira AC. Caracterização da biomassa proveniente de resíduos agrícolas [dissertation]. Cascável: Universidade Estadual do Oeste do Paraná; 2012.

Vital BR. Métodos de determinação da densidade da madeira. Boletim Técnico SIF 1984; (1): 1-21. 